\title{
Strategi Pembelajaran Partisipatif pada Proses Penyelenggaraan Program Paket C di Kabupaten Wajo
}

\author{
Sumarni ${ }^{1}$, Muhammad Nasir ${ }^{2}$, Besse Herlina ${ }^{3}$ \\ Administrasi Pendidikan, Universitas Puangrimaggalatung ${ }^{123}$ \\ Email: sumarnifkip.ap@gmail.com ${ }^{1}$, muhammadnasir@uniprima.ac.id ${ }^{2}$, \\ besseherlina23@gmail.com ${ }^{3}$
}

\begin{abstract}
ABSTRAK: Penelitian ini menelusuri bagaimana perencanaan, pelaksanaan dan evaluasi dalam pembelajaran partisipatif pada penyelenggaraan program paket $C$ di Kabupaten Wajo dengan menggunakan pendekatan kualitatif serta metode studi kasus. Adapun teknik dalam mengumpulkan data adalah: observasi, wawancara mendalam dan dokumentasi. Analisis data meliputi tahap: koleksi data, penyederhanaan data, penyajian data dan penarikan kesimpulan. Hasil penelitian menjelaskan bahwa strategi pembelajaran partisipatif pada proses penyelenggaraan program paket $C$ di Kabupaten wajo meliputi: 1) Tahap perencanaan, mengidentifikasi semua unsur-unsur yang menjadi kebutuhan masyarakat/warga belajar baik sebelum dimulai program maupun dalam pelaksanaan program yang menjadi sumber belajar bersama; 2) Tahap pelaksanaan, menyiapkan berbagai materi-materi sesuai dengan kebutuhan warga belajar, materi tentang sejarah, motivasi kehidupan, bahkan pengalaman. Hal ini bertujuan untuk membagun kembali memori warga belajar yang telah diperoleh selama mengikuti program paket $C$ dan menginterpretasikan pengetahuan sebelumnya dan penyelenggara mengaitkan pengalaman peserta paket $C$ dengan pengalamannya sebagai pegetahuan awal; 3)Tahap penilaian, semua yang menjadi sumber belajar bertujuan memotivasi warga belajar untuk melakukan analisis baik kekurangan dan kelebihan dalam pelaksanaan program paket $C$, baik yang berupa pengalaman terutama terhadap keterampilan yang telah dimiliki di dalam tugas sebenarnya atau dalam dunia kehidupanya
\end{abstract}

Kata kunci: Strategi, Partisipasif, Program Paket C

ABSTRACT: This study explores how the planning, implementation and evaluation of participatory learning in the implementation of the package $C$ program in Wajo District using a qualitative approach and case study methods. The techniques for collecting data are: observation, in-depth interviews and documentation. Data analysis includes the stages: data collection, data simplification, data presentation and drawing conclusions. The results of the study explained that the participatory learning strategy in the process of implementing the package $C$ program in Wajo Regency includes: 1) The planning stage, identifying all elements that are the needs of the community / learning citizens both before starting the program and in implementing the program which become a source of joint learning; 2) The implementation stage, prepares various materials according to the needs of the learning community, material about history, life motivation, and even experiences. This aims to rebuild the memories of learning citizens that have been obtained during the package $C$ program and interpret previous knowledge and the organizers relate the experiences of package $C$ participants with their experiences as initial knowledge; 3) The assessment stage, all of which become learning resources aims to motivate learning citizens to analyze both the weaknesses and strengths of implementing the package $C$ program, both in the form of experience, especially the skills they already have in their actual assignments or in their life.

Keywords: Strategy, Participatory, Program of Package C 


\section{PENDAHULUAN}

Program pendidikan memilki kedudukan yang sangat penting bagi pembagunan seperti halnya dengan program-program lainnya yang bertujuan untuk mengembangkan sumber daya manusia khususunya di Indoenesia. Pengembangan sumber daya manusia adalah bagian dari bentuk pemberdayaan masyarakat dan menjadi masalah tentang kepedulian yang sampai pada saat ini belum terealisasikan sepenuhnya sehingga menjadi pekerjaan yang berputar pada lingkaran terpola secara alamiah dan ini bagian peran penting dari pendidikan non formal.

Pendidikan nonformal merupakan bagian dari pendekatan dasar dalam pembagunan sebagai pelaku tama dalam memberdayakan sumber manusia dalam berbagai sektor. Sehingga pembagunan mampu berjalan dengan baik apabilah sumber daya manusia dikembagkan dan dibekali pendidikan dalam kegiatankegiatannya dalam pembagunan. Sehingga pendidikan nonformal bisa dilaksanakan dibeberapa satuan yang ada, hal ini berdasarkan UU RI Nomor 20 tahun 2003 Sistem Pendidikan Nasional, pasal 26 ayat (4) yang menjelaskan bahwa pendidikan nonformal ini memiliki lembaga-lembaga seperti kursus, pelatihan, kelompok belajar, Pusat Kegiatan Belajar Masyarakat (PKBM), dan majelis taklim, dan juga pendidikan sejenis yang bekerja secara terorganisasi dan sistematis. Wahyu (2018) Pendidikan nonformal ialah setiap kegiatan terorganisasi dan sistematis, diluar sistem persekolahan yang mapan, dilakukan secara mandiri atau merupakan bagian penting dari kegiatan yang lebih luas, yang sengaja dilakukan untuk melayani peserta didik tertentu didalam mencapai tujuan belajarnya. Pendidikan nonformal memiliki tujuan dan kegiatan yang terorganisasi, dilaksanakan dilingkungan masyarakat dan lembaga-lembaga untuk melayani kebutuhan belajar khusus para peserta didik.

Sedangkan Mambili

menjelaskan bahwa: Non Formal Education can be operationally defined as an organised, structured and systimatic learning service delivered outside the framework of formal school system to a specific group Is of people for a specific objective, at low cost in terms of both time and resources". Selanjutnya Pendidikan nonformal memiliki perbedaan dengan pendidikan formal. Sudjana (2010) mengidentifikasi beberapa perbedaan pendidikan nonformal dari pendidikan formal, yaitu: derajat ketaatan dan keseragaman yang lebih longgar dibanding pendidikan formal memiliki bentuk dan isi program yang bervariasi, memiliki teknik-teknik yang berbeda dalam mendiagnosis, merencanakan, dan mengevaluasi proses, hasil dan dampak program pendidikan, tujuan pendidikan nonformal tidak seragam, tidak memiliki persyaatan ketat bagi peserta didiknya, tanggung jawab pengelolaan dan pembiayaan pendidikan nonformal dipikul oleh pihak-pihak yang berbeda, serta sistem penyelenggaraannya yang berbeda dari pendidikan formal.Dari model tersebut yang memiliki beberapa saran sebagai masukkan (instrumental input) yang merupakan pengelolaa dalam program sistem pengembangan pendidikan non formal yaitu keseluruhan dumber dan fasilitas untuk warga belajar dalam kegiatan proses belajar di rangkum isi dari program penyelnggaraan non formal yaitu tujuan program, kurikulum, tenaga pendidik dan kependidikan dan juga beberapa fasilitas dalam sarana dan prasarana belajar bahkan biaya pendidikan.

Sedangkan untuk masukan raw input yang ada dalam bagian dari pengembangan pendidikan non formal dari berbagai karakteristik yang dimiliki oleh warga belajar adalah faktor yang 
paling mendalam, terdapat pada struktur kognitif, psikomotorik atau sikap, minat belajar, skill, dan aspirasi yang bahkan menjadi kebutuhan belajar, hal ini menjadi bagian-bagian dari faktor internal sehingga keadaan peserta didik akan tergambar seperti kebiasaan dalam belajar, status sosial, tingkat pengetahuan dan pendidikan serta keadaan ekonomi yang tergambar dalam keadaan keluarga peserta didik.

Instrumental input yang merupakan masukan dari lingkungan sangat membutuhkan suatu keputusan dalam pengembangan pendidikan, sosial budaya dan ekonomi serta peluang dan daya saing dan skil lainnya merupakan cakupan dari lingkungan yang ada di daerah, sehingga lingkungan wilayah nasional yang cakupannya berupa peraturan, kebijakan dan perkembangan pendidikan nasional saat ini dan beberapa aspekaspek penting yang terkait didalamnya yang meliputi desa dan perkantoran yang sangat membutuhkan karena masih rendah akan pencapaian ekonomi masyarakat. hal-hal yang mencakup ekonomi, teknologi dan hubungan antar negara masih cenderung berubah-ubah mengikuti dari tingkat perkembangan pendidikan yang ada di negara-negara berkembang sehingga, perubahan yang ada masih perlu pengembagan baik yang ada di lingkungan wilayah nasional dan internasional sebagai titik masa depan negara.

Hersey dan Blanchard (Sudjana, 2004) mengemukakan bahwa management as working together with or through other people, individuals orgroups, to accomplish organitational goals yang saling bekerjasama satu sama lain baik secara induvidu maupun berkelompok dalam pencapai tujuan. Memiliki strategi dalan pengelolaan pendidikan non formal dengan menggunakan organisasi dan organisasi itulah dinamakan lembaga pusat kegiatan belajar masyarakat (PKBM) atau lembaga pendampingan PKBM terorentasi ke kedepan. Menurut Hiryanto (2009), meskipun awal berdirinya banyak PKBM yang bergantung pada bantuan dan dana block grant dari pemerintah, dalam jangka panjang diharapkan pada sebagian besar PKBM akan tumbuh kemandirian, dalam hal ini peran dominan pemerintah yang selama ini menjadi semakin berkurang dan lebih pada peran fasilitasi akan dapat berjalan seiring dengan kemandirian PKBM. PKBM akan berdiri kokoh atas keswadayaan masyarakat

Rizka dkk (2017), Pusat Kegiatan Belajar Masyarakat (PKBM) merupakan prakarsa pembelajaran masyarakat yang didirikan dari, oleh dan untuk masyarakat. PKBM adalah suatu institusi yang berbasis masyarakat (Community Based Institution). Sebagai institusi yang didirikan oleh, dari dan untuk masyarakat, PKBM memiliki potensi sebagai institusi yang mandiri.

Karim (2017), keterlaksanaan pendidikan non formal sebagaimana di PKBM, yakni belum sepenuhnya menjadi program unggulan baik oleh pemerintah maupun lembaga mitra pemerintah seperti lembaga swadaya masyarakat (LSM) atau lainnya, karena beberapa pertimbangan. Pertama, kesulitan menemukan program aksi yang layak menjadi materi pendidikan sekaligus menghasilkan output yang memiliki peluang pasar secara berkelanjutan. Kedua, keterbatasan dana yang dapat menjamin ketersediaan modal kerja sebagai tindak lanjut dari implementasi pendidikan. Ketiga, menyangkut kurangnya kesiapan sumber daya manusia baik sebagai peserta didik maupun sebagai fasilitator untuk mendukung terselenggaranya kegiatan pendidikan. Namun, dengan fleksibilitas program, pendidikan di PKBM bisa menjadi alternatif untuk mempersiapkan dan mendorong perkembangan peluang 
kerja sesuai dengan karakteristik kebutuhan dan kondisi tertentu. Hal tersebut terjadi karena program disesuaikan dengan perubahan kebutuhan peserta didik dan perkembangan lingkungan.

Perencanaan serta program dalam strategi penyelenggaraan pendidikan non formal diselenggarakan melalui PKBM, sehingga strategi pengelolaanya terarah dalam satu rencana dalam menerapkan fungsi-fungsinya sebelum masuk pada tahap penilaian yaitu sebagai perencanaan, pengorganisasian, penggerakan, pembinaan itulah strategi pengelolaan dengan tujuan peningkatan kualitas program pendidikan non formal di PKBM. Selain itu, PKBM memiliki pendekatan kolaboratif yang diracang dari segi pengelolaan untuk menggali dan memberdayakan masyarakat dengan lingkungan dengan cara mensosialisasikan program sehingga masyarkat lain mampu memodifikasi dari berbagai pihak-pihak yang terkait dan menjadi pendukung dalam pelaksanaan kegiatan PKBM sehingga pendekatan kolaborasi dilakasanakan secara terencana dan inovatif, dan melahirkan komitmen baru dan gagasan yang terupdate dalam pemecahan masalah yang dihadapi warga belajar, contonya pendidikan luar sekolah yang unsurnya harus mencakup tiga unsur pokok dalam perencanaan.

Pelaksanaan program pemerhati pendidikan baik dari pemerintah maupun swasta secara sinergik kepada masyarakat memiliki komitmen dalam pemecahan masalah yang dihadapi masyarakat sehingga perlu adanya pengerahan sumber daya manusia sebagai komitmen kegiatan lembaga baru dalam pelaksanannya dengan menggunakan pendekatan partisivatif oleh PKBM yakni partisipasi masyarakat baik dari perencanaan, pelaksanaan dan penilaain dalam proses pembelajaran dari kegiatan program yang berlangsung .

$$
\text { Pelaksanaan pengembangan }
$$

program berlangsung di masyarakat disusun dalam rencana strategik dengan proses pengumpulan informasi-informasi tentang masalah internal yang ada di PKBM tersebut dan dideskripsikan berdasarkan hasil kajian pustaka dan empirik, sehingga terbentuk 7 poin yaitu : 1). Sejarah PKBM, 2). Manajemen organisasi PKBM, 3). Penerapan program, 4). Kerjsama dengan berbagai instansi yang terkait sebagai dukungan PKBM, 5). Tenaga tutor dan fasilitas pendukung, 6). Kurikulum dan implementasinya, dan 7). Hasil SWOT PKBM.

Sedangkang dari informasi dari isu lingkungan eksternal dapat di kaji dari beberapa poin sebagai berikut : 1 ). Luaran PKBM untuk masyarakat, 2). Terpenuhinya kebutuhan belajar masyarakat, 3). Peluan masa dengan PKBM, 4). Perubahan dan pengaruh PKBM di, dan 5). peluang dan tantangan PKBM.

Partisispasi masyarakat dan lintas
sektoral dianggap sangat penting
sehingga mmebutuhkan pengembangan
dari penyelenggara program pendidikan
non formal yang ada di PKBM karena
melihat dari beberapa informasi di atas yang diperoleh dari lingkungan PKBM maka dapat diketahui ada beberapa dari setiap poin-poin menjadi pembeda pada tiap isu, dan memiliki keterakaitan dari poin yang satu dengan yang lainnya. Sehingga dalam menyusun tingkatan dari poin informasi tersebut di rangking berdasarkan kepentingan. Sehingga penelitian ini bertujuan mengungkap perencanaan, pelaksanaan dan evaluasi pembelajaran partisipatif pada pelaksanaan program paket $\mathrm{C}$ di kabupaten Wajo.

Dari hasil paparkan yang ada, terdapat unsur-unsur partisipasi masyarakat sebagai pendekatan 
meningkatan hasil penyelenggaraan program Pendidikan Nonformal di PKBM secara sempurna. sehingga, penelitian ini mencoba memecahkan masalah yang pada penyelenggaraan pendidikan non formal di Kabupaten Wajo dengan fokus pada sistem pembelajaran partisipatif.

\section{METODE}

Schwand (Cresswell, 2013), sesuai dengan tujuan dari penelitian ini adalah menuliskan istilah dari "teknis" yang ada sehingga menggunakan bahasa penelitian kualitatif dan metode studi kasus sebagai upaya dalam mendeskripsikan kasus yang ada di lapangan secara detail sehingga analisis tema atau masalahnya mampu di interpretasikan dengan penegasan kasus, olehnya itu peneliti menggunakan pendekatan kualitatif, yang merupakan suatu gejala utama dan dieksplorasikan dalan penelitian ini serta partisipasi masyarakat dalam setting dan latar penelitian.

Peneliti berusaha untuk mengungkap dan meganalisis pembelajaran partisipatif dalam penyelenggaraan pendidikan non formal secara detail di PKBM Kabupaten Wajo sebagai subyek penelitian penyelngara lembaga dalam program pendidikan non formal melalui studi kasus dengan lokasi di Kecematan Tangsitoloh Desa Pakkanna dengan PKBM "Hati Mulia" yang setiap tahunnya mampu meluluskan banyak warga belajar, seperti tahun ini ada 34 warga belajar yang ikut Ujian Nasional Berbasis Kompetensi (UNBK) tampah mengalami gangguan apapun.

Sesuai dengan metode yang telah dijelaskan sebelumnya, maka peneliti mengumpulkan data-data dengan cara observasi, wawancara mendalam, dan analisis dokumentasi. Observasi merupakan cara dalam mengambil datadata yang sesuai dengan fokus penelitian. Wawancara dan kuisioner selalu berintraksi secara lisan dengan orang yang merupakan sumber data, sedangkan observasi tidak memiliki batasan berapa jumlah orang, serta gejalah-gejalah alam yang dialaminya. Sedangkan wawancara, merupakan proses perolehan data melalui informasi dari berbagai pihak yang terkait sehingga membentuk suatu ide dalam percakapan yang terjalin dari satu sama lain, dikonstruksikan sebuah kode dari klasifikasi data yang ada. Dalam penelitian ini, peneliti menerapkan tehnik wawancara tidak terstruktur, kisi- kisi instrumen sederhana sebagai pedoman wawancara. Pedoman wawancara tersebut disusun sederhana dan hanya dimaksudkan agar wawancara lebih terarah sehingga informasi yang dibutuhkan dapat lengkap dan jelas. Sebagaimana dijelaskan bahwa wawancara tidak berstruktur adalah komunikasi lepas tidak harus sesuai dengan pedoman yang telah dibuat peneliti. Sedangkan yang terstruktur suatu komunikasi yang harus tetap dijaga oleh peneliti selama proses komunikasi dalam mengumpulkan data penelitian dan poin-poin masalahnya dijadikan sebagai garis besar dalam permsalahnya.

Begitu banyak kesempatan yang mampu dimanfaatkan dalam pelaksaan Pengumpulan data, yaitu 1). Peneliti bertemu langsung dan mendiskusikan pelaksanaan PKBM dalam strateginya secara mendalam, 2). Melakukan wawancara pada informan, 3). Mendokumntasikan semua berkas/ dokumen menjadi alat dalam menkaji penelitian ini terutama dokumntasi yang berhubungan dengan proses kegiatan belajar mengajar antara lain, foto-foto kegiatan, daftar warga belajar, serta hasil karya warga belajar.

Miles \& Huberman (Sugiyono, 2011) mencoba mengembangkan suatu model dalam menganalisis data-data yang terkumpul di lapangan, sampai pada selesainya pengumpulan data, dan penyusunan draft laporan hasil penelitian 
sehingga analisis datanya dilakukan selama proses penelitian berlangsung dengan model analisisinteraktif (interactive model of analysis).

Proses dari pengkalsifikasian dan pemilihan serta pemusatan perhatian dalam kesedrhanaan data sehingga peneliti mampu merangkum abstrak dan transformasiikan data-data yang masih mentah dari lapangan itulah reduksi data. Analisis data dilakukan tiga komponen, yaitu : analisis reduksi data yang telah di peroleh saat di lapangan dan di buatkan dalam bentuk laporan secara terperinci, setelah itu laporan lapangan direduksi, dirangkum dan sesuai dengan pokok masalah yang ada, kemudian difokusukan pada pencarian tema sesuai dengan pola metode yang digunakan. Pada saat menreduksikan data secara langsung dan terjadi secara terus menerus, selanjutnya peneliti membuat ringkasan, mengkode, dan menelususri tema yang telah dipilih. oleh karena itu dalam menarik sebuah simpulan akhir dan menverivikasi terlebih dahulu peneliti mereduksi data dalam menganalisis, menklasifikasian, dan memilih, serta mengorganisasikannya.

Yang merupakan konsep awal sebagai pijakan untuk menganalisis data ,mereduksi untuk mendapatkan data hasil wawancara, obeservasi, dan dokumen dari tutor, kemudian disederhanakan menjadi catatan maupun diskripsi data yang berupa kata-kata tertulis.

\section{HASIL DAN PEMBAHASAN}

\section{Perencanaan Pembelajaran Partisipatif dalam Penyelenggaraan Program Paket C Kabupaten Wajo}

Perencanaan

pembelajaran program Paket C Kabupaten Wajo, terdiri dari tahapan:

1. Terdapatnya pengurus dalam mendampingi peserta belajar menganalisis yang menjadi kebutuhan belajar sesuai dengan tujuan sehingga mampu mengiidentifikasi need dalam proses pembelajaran belajar secara menyeluruh yang dilakukan oleh pengurus PKBM dalam melaksanakan program pendidikan paket $C$, untuk meningkatkan pengetahuan, sikap dan skill yang menjadi tujuan belajar. Adanya semangat partisipatif warga belajar dalam kegiatan menganalisis kebutuhan belajar, sumber dan kemungkinan hambatan program pendidikan nonformal yang akan dilaksanakan di PKBM menjadi satu kesatuan dalam pelaksanaan pembelajaran partisipatif.

Penyelenggara membantu warga belajar dalam penyusun tujuan belajar. Sehingga tujuan pembelajaran dilakukan berdasarkan tiga alasan. 1) Untuk mengarahkan pada proses pembelajaran. 2) Sebagai dasar untuk pelaksanaan pembelajaran dan pengadaan unsur unsur belajar yang tepat. 3) Titik ukur dalam evaluasi kegiatan belajar yang dilaksanakan di PKBM.

Penyelenggara PKBM dan warga belajar memilih prioritas tujuan belajar dari masalah, peluan dan tantangan yang tersedia atau yang dapat diselesaikan. Serta adanya keterlibatan semua pihak dalam merumuskan tujuan belajar dalam implementasi dan komponenkomponen yang terdapat di dalannya sehingga menjadi penentu dalam proses belajar megajar yang di ingikan, seperti proses pembelajaran, sistem evaluasi, sarana dan prasarana, dan pembiayaan.

Perencanaan dan perencanaan penentuan kebutuhan dalam warga belajar, penyelenggara PKBMharus mampu menganalisis dan memperhatikan secara detail dengan tujuan membantu peserta dalam menerapkan semua prinsip-prinsip penyelenggraan PKBM mulai dari hal 
terkecil hingga kebutuhankebutuhan yang diaggap besar dalam menentukan model pembelajaran yang di inginkan karena hal ini menjadi modal dalam bersosial, dan budaya dalam penentuan sumber daya manusia serta sumber daya alam yang ada menjadi pendukung dalam penyelenggaraan PKBM.

2. Warga Belajar menyiapkan Kelompok belajar serta melibatkan semua peserta dalam perencanaan kegiatan belajar. kegiatan belajar dilaksanakan kelompok secara terbatas. Sehingga pembelajaran dapat berlangsung efektif dan efisien karena jumlah anggota kelompok tidak terlalu besar. Adapun dalam penyelengaraan kelompok belajar pendidikan nonformal menngandung 4 unsur yang ada di PKBM, yaitu adanya kebutuhan bersama, motivasi, reaksi cakap, struktur organisasi, serta adanya aturan kelompok. Antar anggota kelompok dapat saling membelajarkan satu sama lain, dan dapat menjadi sumber belajar dari pelaksanaan program pendidikan nonformal yang dilaksanakan di PKBM.

3. Menyusun dan menetapkan program pendidikan nonformal semua fasilitas dalam proses pembelajaran yaitu sarana dan prasarana, teknik atau metode. Sedangkang pada tahap perencanaan pembelajaran pendidikan nonformal di PKBM ini dilakukan proses pembinaan keakraban, di analisis berdasarkan kebutuhan belajar, sumber belajar dan kemungkinan hambatan belajar, tujuan dari pembelajaran dan menyusunan program pembelajaran.

Adapun keuntungan perencanaan pembelajaran partisipatif dalam implemtasi pendidikan nonformal PKBM antara lain:
1. Kebutuhan belajar secara terorganisasi dan dikelola oleh warga belajar dan dilakukan secara berkelompok

2. Penyelengara PKBM menerapkan program pendampingan sebagai upaya peningkatan proses belajar yang lebih mengutamakan pada kompone dan perubahan etika dan karakter warga belajar.

3. Penyelengara PKBM merupakan suatu upaya pemerintah untuk meningkatkan tarah kehidupan masyarakat karena PKBM berorentasi pada autput.

4. Sumber-sumber yang dilaksanakan berdasarkan pendampingan masyarakat yaitu pemberdayaan masyarakat yang sistemnya dari masyarakat untuk masyarakat.

5. Pendampingan fokus pada pemberdayaan masyarakat bertujuan menggali potensi-potensi, skill, sumber daya manusia dan sumber daya alam yang ada di Kabupaten Wajo khususnya bagi penyelenggara PKBM.

\section{Implementasi Pembelajaran Partisipatif pada Program Paket C di Kabupaten Wajo}

Penyelengaraan PKBM dalam dalam proses pembelajaran pendidikan nonformal dalam menghadapi berbagai permasalahan seperti menangani kekurang berhasilan pendidikan formal dalam peningkatan keterampilan secara fungsional dalam pengembangan kewirausahaan masyarakat. Suatu upaya dalam proses pemdampingan kewirausahaan sesuai yang ada di lingkungan menjadi peluang untuk dunia industri.

Penyelenggaraan jalur nonformal merupakan program pemerintah yang bejalan secara terstruktur dan terorganisis yang dilaksanakan secara sendiri namaun sangat memberikan 
output bagi masyarakat karena dalam tahan penyelenggaraanya memberikan layanan khusus bagi masyrakat dalam pencapaian tujuan bersama dalam penerapan pembelajaran partisipatif Coombs (Kamil, 2009). Karena warga belajar merupakan bagian dari wujud tiga tahapan yaitu perencanaan program (program planning), pelaksanaan program (program implementation) dan penilaian program (program evaluation) kegiatan pembelajaran.

Adapun tahap implemtasi pembelaran pastisipatif di PKBM dalam program paket $C$ di Kabupaten Wajo adalah sebagai berikut:

1. Terjalinnya hubungan yang terbuka, keakraban yang terarah satu dalam proses pembelajaran.

2. Terjalinya intraksi hubungan horizontal yang sejajar dari semua pihak yang terkait, baik dari penyelenggra program paket $\mathrm{C}$, masyarakat, totur dan pihak-pihak yang terkait.

3. Proses pembelajaran lebih ditekankan keaktifan dan partisipas masyarakat.

4. Proses pembelajaran dilakukan sesuai dengan jadwal yang telah disusun oleh penyelenggara bersama dengan masyarakat atau peserta.

Adapun tujuan utama dalam implementasi pembelajaran partisipatif, peran pengurus PKBM adalah untuk :

1. Menposisikan diri pada posisi tidak mengetahui secara keseluruhan, tetapi menggunakan prinsip saling membelajarkan.

2. Mendampingi masyarakat melaksakan pembelajaran sesuai apa yang mereka ingingkan dan yang apa yang menjadi kebutuhan masyarakat atau peserta belajar.

3. Memberikan motivasi kepada masyarakat untuk ikut berpartisipasi dalam menyusun tujuan program, bahan yang dibutuhkan dalam program serat cara pelaksanaan program.

4. Menempakan kedudukannya sebagai warga belajar untuk saling belajar di dalam kegiatan belajar.

5. Tutor dan masyarakat sebagai warga belajar paket $\mathrm{C}$ menjalin hubungan emosial sehingga antara tutor dan warga belajar menjadi mitra komunikasi dalam berbagi ilmu pengetahuan dan pengelaman.

6. Terjalinnya suasana kondusif dalam proses pembelajaran dan semangat belajar dan bertukar pikiran.

7. Mampu membentuk kelompok sebagai wadah pengoptimalan respon trhadap stimulus yang ada baik saat proses pembelajaran maupun di luar kegiatan pembelajaran.

8. Mampu memberikan spirit bagi warga belajar dalam menhdapai kompetisi, semanga bersaing, dan juga semangat menata masa depan mereka.

9. Memberikan pendampingan kepada warga belajar tentang pendekatan dalam memecahkan masalah yang mereka hadapi.

10. Memberikan trik bagaimana berikir yang cerdas dan bertindak cerdas dalam menhadapi dunia ini.

Metode dalam pembelajaran partisipatif merupakan kegiatan atau cara umum penggolongan peserta didik dalam kegiatan program pendidikan nonformal di PKBM. Model pembelajaran yang menggunakan metode khusus dalam pendidikan yang berjalan secara teratur hal ini dinamakan model pembelajaran partisipatif. Metode dan teknik yang digunakan dalam pembelajaran partisipatif dapat digolongkan sebagai berikut:

1. Metode pembelajaran individual, teknik yang digunakan: tutorial, bimbingan perorangan, pembelajaran individual, magang dan lain sebagainya. 
2. Metode pembelajaran kelompok, teknik yang digunakan: diskusi, simulasi, kerja kelompok, pemecahan masalah, bermain peran, dan lain sebagainya.

3. Pembelajaran dilakukan dengan menggunakan metode massal, teknik yang digunakan: kontak sosial, paksaan sosial, demonstrasi, aksi partisipasi dan lain sebagainya.

\section{Evaluasi Pembelajaran Partisipatif dalam Program Paket $\mathbf{C}$ di Kabupaten Wajo}

Tahap penilaian pembelajaran merupakan penting untuk mengetahui keberhasilan program pendidikan nonformal di PKBM. Penialaian dilakukan untuk membagi, mengelolah serta menyajikan data atau informasi yang dapat digunakan sebagai masukan dalam pengambilan keputusan. Evaluasi program pendidikan nonformal di PKBM dilakukan bersama antara warga belajar dan pengurus PKBM. Melalui kegiatan penilaian program pendidikan nonformal di PKBM ini, Masyarakat mengetahui sejauh mana perubahan yang telah dialami dan dicapai oleh mereka melalui kegiatan belajar. Tercapainya tujuan belajar akan mempengaruhi warga belajar dalam dua hal. 1). mereka mempunyai pandangan tentang tingkat kemampuan yang telah dicapai melalui kegiatan belajar. 2). Mereka diharapkan akan ada perubahan tingka laku baru yang dimiliki sehingga menjadi manusia dan mampu dikembangkan.

Ada tiga cakupan yang sangat berpengaruh dalam kegiatan belajar, yaitu 1). Adanya perubahan perilaku dari lulusan, baik dari pekerjaan, pendapatan, kesehatan. 2). Adanya perolehan manfaat dari upaya membelajarkan orang lain. 3). Membagun rasa partisipasi dari warga lulusan.

\section{SIMPULAN}

Dari hasil yang dikemukakan di atas dari analisis data maka dapat disimpulkan ada beberapa tahap yang dilakukan dalam pembelajaran partisipatif yaitu:

1. Tahap perencanaan. Penyelenggara mengidentifikasi semua unsur-unsur yang menjadi kebutuhan masyarakat/warga belajar baik sebelum dimulai program maupun dalam pelaksanaan program yang menjadi sumber belajar bersama.

2. Tahap pelaksanaan yaitu penyelenggara menyiapakan berbagai materi-materi sesuai dengan kebutuhan warga belajar, materi tentang sejarah, motivasi kehidupan, bahkan pengalaman, hal ini bertujuan untuk membagun kembali memori warga belajar yang telah diperoleh selama mengikuti program paket $\mathrm{C}$ dan menginterpretasikan pengetahuan sebelumnya, dan penyelenggara mengaitkan pengalaman peserta paket C dengan pengalamannya sebagai pegetahuai awal.

3. Tahap penilaian, semua yang menjadi sumber belajar bertujuan memotivasi warga belajar untuk melakukan analisis baik kekerangan dan kelebihan dalam pelaksanaan program paket $\mathrm{C}$, baik yang berupa pengalaman terutama terhadap keterampilan yang telah dimiliki di dalam tugas sebenarnya atau dalam dunia kehidupamya

Ketiga tahap di atas merupakan merupakan usaha dalam meningkatkan kepercayaan diri para warga belajar dan keterampilan yang mereka miliki, itulah implemntasi pembelajaran partisipatif dalam program paket $\mathrm{C}$ di kabupaten Wajo.

Sebagai tindak lanjut dari penelitian ini, ada beberapa saran bagi penyelenggara program paket C pada PKBM, yaitu : 
1. Dijadikan masukan untuk meningkatkan dan mengembangkan program pendidikan nonformal sesuai dengan satuannya dan potensi lokal di sekitarnya, pihak penyelenggara program pendidikan nonformal memberikan kesempatan belajar bagi wargabelajar yang ingin meningkatkan partisipasinya sesuai dengan kemampuannya masingmasing, penyelenggara menjalin kerjasama dengan berbagai pihak yang terkait, baik pemerintah maupun swasta sehingga semuannya menjadi pendukung dalam implementasi program paket $C$ dan bermitra dengan penyelenggara PKBM.

2. Bagi peneliti lain bahwa penelitian ini masih banyak memiliki keterbatasan ditinjaudari segi metode penelitian dan masalahpenelitian yang dikaji. Pendekatan kualitatif dan metode studi kasus yang digunakan terbatas pada beberapa subyek penelitian sehingga pengelolaan program pendidikan nonformal belum dibahas secara lengkap. dan pengembangan program pendidikan nonformal di PKBM lain.

\section{UCAPAN TERIMA KASIH}

Penulis mengucapkan banyak terimakasih kepada semua pihak yang telah membantu terselesaikannya tulisan ini. Penulis juga menyampaikan penghargaan kepada tim editor JET FKIP UM Kendari atas kesediaannya menyediakan outlet untuk mempublish tulisan ini.

\section{DAFTAR PUSTAKA}

Cresswell, John W. (2013). Research Design. Yogyakarta. Pustaka Pelajar.

Hiryanto. (2009). Strategi Pengelolaan dan Pengembangan Pusat Kegiatan Belajar Masyarakat
(PKBM). Makalah pada Pelatihan Tenaga Pendidik PKBM.

Karim, Abdul. (2017). Efektivitas Partisipasi Perempuan Pada Pendidikan Non Formal di Pusat Kegiatan Belajar Masyarakat (PKBM) Kecamatan Wedarijaksa Kabupaten Pati. INFERENSI, Jurnal Penelitian Sosial Keagamaan. Vol. 11, No.1, Juni 2017 : 119-140. DOI: https://doi.org/10.18326/inf sl3.v11i1.119-140

Mambili, E. (2004). The Position of NonFormal Education in Kakamega District in the Face of Declared Free Primary Education, Accessing Ouality Basic Education Trough Non-Formal Education, LIFA Programme Coordinator.

Rizka, Muhammad dan Hardiansyah, Arief Rila. (2017). Analisis Strategi Fund Raising dalam Penyelenggaraan Program Pendidikan Nonformal pada Pusat Kegiatan Belajar Masyarakat Ceria. Journal of Nonformal Education: NE 3 (2) (2017): 165-172.

Sudjana, Djudju. (2004). Manajemen Pendidikan Nonformal. Bandung: Fallah Production.

Sudjana. (2010). Pendidikan Nonformal, Wawasan Sejarah Perkembangan Filsafat Teori Pendukung Asas. Bandung: Falah Production.

Sugiyono. (2011). Metode penelitian. Bandung: Alfabeta

Undang-Undang RI Nomor 20. 2003. Sistem Pendidikan Nasional.

Wahyu Bagja Sulfemi. (2018). Modul Pendidikan Non Formal. Program Studi Administrasi Pendidikan STKIP Muhammadiyah Bogor. 